\title{
Incidence of storage fungi and hydropriming on soybean seeds ${ }^{1}$
}

\author{
Denis Santiago da Costa ${ }^{2 *}$, Nathalie Bonassa ${ }^{3}$, Ana Dionisia da Luz Coelho Novembre ${ }^{2}$
}

\begin{abstract}
Priming is a technique applicable to seeds of various plant species; however, for soybean seed there is little available information correlating such technique to the storage fungi. The objective of this study was to assess hydropriming on soybeans seeds and correlate this technique to occurrence of such fungi. For this, soon after acquisition the soybean seeds, cv. M-SOY 7908 RR, were characterized by: moisture content, mechanical damage, viability (seed germination and seedling emergence) and seed health. A completely randomized experimental design was used with treatments arranged into a factorial scheme $2 \times 2$ [2 levels of incidence of storage fungi (low and high) $\times 2$ hydropriming (with and without) ]. After application of treatments, the seeds were analyzed by: moisture content, viability (seed germination and seedling emergence) and vigor (first count and accelerated aging). The hydropriming is beneficial to improve the quality of soybean seeds with low incidence of storage fungi, with increments on speed germination (first count) and seed germination after accelerated aging test. The high incidence of microorganisms can reduce the hydropriming benefits.
\end{abstract}

Index terms: priming, Aspergillus spp., Penicillium spp., Glycine max.

\section{Incidência de fungos de armazenamento e hidrocondicionamento de sementes de soja}

\begin{abstract}
RESUMO - O condicionamento fisiológico é uma técnica aplicável às sementes de várias espécies vegetais. No entanto, para as sementes de soja não há informação disponível, relacionando esta técnica com os fungos de armazenamento. Desta forma, o objetivo dessa pesquisa foi avaliar a interação entre o hidrocondicionamento de sementes de soja e a incidência desses fungos. Foram avaliadas sementes de soja, cultivar M-SOY 7908 RR, que, logo após a aquisição, foram caracterizadas quanto ao teor de água, dano mecânico, viabilidade (testes de germinação e emergência da plântula) e sanidade. O delineamento experimental utilizado foi o completamente ao acaso com tratamentos arranjados em esquema fatorial $2 \times 2$ (alta e baixa incidência de fungos $\times$ com e sem hidrocondicionamento). Após a aplicação dos tratamentos as sementes foram avaliadas quanto: ao teor de água, à viabilidade (germinação das sementes e emergência da plântula) e ao vigor (primeira contagem e envelhecimento acelerado). O hidrocondicionamento, quando aplicado em sementes de soja com incidência baixa de microrganismos de armazenamento, é benéfico para aprimorar a qualidade das sementes, com incremento da velocidade de germinação (primeira contagem) e da germinação após o teste de envelhecimento acelerado. No entanto, a incidência alta desses microrganismos prejudica os benefícios do hidrocondicionamento.
\end{abstract}

Termos para indexação: condicionamento fisiológico, Aspergillus spp., Penicillium spp., Glycine max.

\section{Introduction}

For the soybean crop, achievement of high yields is directly correlated to favorable environmental conditions during all vegetative and reproductive stages of plants. Seed germination and seedling emergence in the field are the most critical steps of reproductive process, once unfavorable environmental variations can directly interfere on establishment of crop and, consequently, on productivity.

${ }^{1}$ Submitted on 11/25/2011. Accepted for publication on 09/05/2012. ${ }^{2}$ Departamento de Produção Vegetal, USP - ESALQ, Caixa Postal 9, 13418-900 Piracicaba, SP, Brasil. Bolsistas CNPq.
This manner, aiming at improving seed quality for an adequate establishment of plant population in the field, researchers have assessed techniques that standardize seed performance of a given lot or enhance specific components of their quality, once recovery of their physiological potential is impossible.

Priming is a technique applied to seeds before sowing aiming at influencing development of seedlings by induction in metabolic activities, which generally accelerate germination and standardize development of seedlings (Bradford, 1986).
${ }^{3}$ Departamento de Entomologia, Fitopatologia e Zoologia Agrícola, USP-ESALQ, Caixa Postal 9, 13418-900 - Piracicaba, SP, Brasil.

*Corresponding author <denis.esalq@gmail.com> 
In addition to these benefits other are attributed to seed priming, as tolerance to stresses during germination (Fanti and Perez, 2003) and overcoming of seed dormancy on some species (Nascimento, 2003). However, beneficial effects of seed priming depend on several factors such as: genotype (Kikuti and Marcos-Filho, 2009); initial quality of seeds (Costa and Villela, 2006); treatment period (Kikuti et al., 2005); temperature (Lima et al., 2004); water absorption speed (Nascimento and Aragão, 2002); seed hydration degree (Fanan and Novembre, 2007); aeration (Pereira et al., 2008); and type of drying (Caseiro and Marcos-Filho, 2005).

It is also essential assessing seed health for priming, once such technique is preformed under environmental conditions that contribute for development of microorganisms (Nascimento and West, 1998).

Among fungi associated to soybean seeds those occurring during storage are the most important, since they are able to grow under environmental conditions relatively dry where field fungi cannot grow and/or develop, resulting in physiological potential reduction, as well as on production of substances (toxins) that are toxic to seeds and humans. Francisco and Usberti (2008) identified that the phenological conditions for these microorganisms is directly correlated to the moisture content of seeds and the storage temperature. Studying storage of soybean seeds, Cardoso et al. (2004) observed that there is a high incidence of the storage fungi Aspergillus spp. and Penicillium spp., when these seeds have high initial moisture content.

Thus, it is possible that during the priming the increase on moisture content of seeds may favor development of microorganisms associated to them. Several studies have been performed for assessing applications of priming techniques on seeds, with promising results for physiological potential of soybean seeds (Mercado and Fernandez, 2002; Arif et al., 2008; Giurizatto et al., 2008; Bejandi et al., 2009; Sadeghi et al., 2011). However, there are still no results referring to influence of microorganisms associated to soybean seeds priming. Therefore, the objective of this study was to assess hydropriming on soybean seeds as well as interference of such technique in relationship with storage fungi.

\section{Material and Methods}

The study was performed using soybean seed [Glycine $\max ($ L.) Merrill], cultivar M-SOY 7908 RR, classified by screen no. 7.0, which soon after acquisition were characterized by moisture content, mechanical injuries, viability (seed germination and seedling emergence), and seed health as following described:

Moisture content: was assessed by the oven method, at
$105{ }^{\circ} \mathrm{C} \pm 3{ }^{\circ} \mathrm{C}$, during $24 \mathrm{~h}$, using two samples of $5 \mathrm{~g}$ each (Brasil, 2009). Results were expressed in percentage moisture content, in wet basis.

Sodium hypochlorite test: it was conducted with two replications of 100 seeds each. For each replication, it was recorded the number of seeds with visible mechanical damages. Seeds without these visible damages were placed into plastic cups $(200 \mathrm{~mL})$ into which then was added a sodium hypochlorite solution in an amount sufficient for that all seeds remained immersed. After a period of 10 minutes, the number of seeds with expanded seed coat was also recorded (Krzyzanowski et al., 2004). Total number of mechanical damaged seeds was obtained by the sum of seeds with visible mechanical damages and the number of seeds with expanded seed coat during the test. Results were expressed in percentage of mechanically damaged seeds.

Germination test: samples of 200 seeds was randomly collected and split into four replications of 50 seeds each that were then evenly distributed on two sheets of Germitest ${ }^{\circledR}$ paper, covered with another sheet of the same paper type moistened with water in an amount equivalent to 2.5 times the weight of dry substrate, and kept into a seed germinator, at $25{ }^{\circ} \mathrm{C}$. For first count of germination, performed at the fifth day after test start, were recorded only the seedlings presenting all parts well developed and surpassing $6.5 \mathrm{~cm}$ in length (value established in function of preliminary tests with seeds of the cultivar assessed; non-published data). In the eighth day after test installation the final counting was performed, recording the number of all normal seedlings, according to Rules for Seed Testing (Brasil, 2009). Results for seed germination and first count were expressed in percentage of normal seedlings.

Seedling emergence: it was conducted in greenhouse conditions with four replications of 50 seeds each for each treatment, which were then sown on sand substrate moistened at 60 of water retention capacity, at $5 \mathrm{~cm}$ deep. Assessments were daily performed until the seventh day and results were expressed in percentage of emerged seedlings and seedling emergence speed index (Maguire, 1962).

Health test: it was performed using the blotter test method by the incubation of 20 replications of 10 seeds each per treatment and then kept into a growth chamber with photoperiod of 12/12 $\mathrm{h}(\mathrm{L} / \mathrm{D})$, at $20 \pm 2{ }^{\circ} \mathrm{C}$, during 10 days, according to RST. Fungi identification was performed with the aid of a stereomicroscope and the values of results were expressed in percentage of occurrence of each fungus, with only one decimal.

The fungi incidence treatments as high or low was based on results attained in health test used for initial characterization of seeds, as well as those obtained after application of mixture fungicide carboxin + thiram. 
The carboxin + thiram $\left(50 \mathrm{~g}+50 \mathrm{~g}\right.$ a.i. $100 \mathrm{~kg}^{-1}$ seeds $)$ was applied to seeds in a solution of fungicide + distilled water in a volume corresponding to $0.5 \%$ of weight of seeds. For application of fungicide, the solution was poured into a transparent plastic bag $(38 \mathrm{~cm}$ long $\times 31 \mathrm{~cm})$ that immediately after was tightly closed and manually shaken until completely covering the seeds.

For the hydropriming procedure were used six sheets of Germitest ${ }^{\circledR}$ paper, moistened with a volume corresponding to 2.5 times the weight of dry substrate. Subsequently, an aluminum tray $(28.5 \mathrm{~cm} \times 18.0 \mathrm{~cm} \times 3.5 \mathrm{~cm})$ was lined with three paper sheets (longitudinally half-folded), where $300 \mathrm{~g}$ of soybean seeds were evenly arranged in a single layer, covered with other three sheets of the same paper also longitudinally half-folded. Immediately after such procedure, the aluminum tray containing the seeds was packed into a plastic bag with about 20 perforations and kept into a germinator chamber, adjusted to $20^{\circ} \mathrm{C} \pm 1{ }^{\circ} \mathrm{C}$, during $48 \mathrm{~h}$. At end of this period, the primed seeds were dried into a forced air circulation drying oven, at $30^{\circ} \mathrm{C}$, until reaching moisture content next to the initial value, i.e., 9.9\% moisture content, expressed in wet basis.

After treatment, the seeds were assessed by moisture content, viability (germination and seedling emergence) and vigor [first count and accelerated aging(AA)]. The AA test cited was performed in the following manner: four samples, 220 seeds each, were evenly distributed in a single layer, on top of a stainless screen fixed on the upper edge of a plastic box containing at bottom $40 \mathrm{~mL}$ of water. After 48 hours at $41^{\circ} \mathrm{C}$ (Baalbaki et al., 2009), the seeds were sown, as previously described for germination test, and assessed at the fifth day after the sowing. Results were expressed in percentage of normal seedlings.

A completely randomized experimental design was used with four replications, with treatments arranged in a factorial scheme 2 (high and low incidence of storage fungi) $\times 2$ (with and without hydropriming). Data were assessed by ANOVA and means were compared by Tukey test, at $5 \%$ probability. When presenting non-normal distribution percentage, data were transformed in arcsen $\sqrt{ } \times 100$ and only the transformation differences are presented accompanied by original mean.

\section{Results and Discussion}

The germination test results were higher than $80 \%$, which is the minimum value established by the standards for soybean seed commercialization in Brazil (Brasil, 2005). However, results achieved in preliminary studies performed for initial soybean seed quality, have indicated that the seeds contained $9.9 \%$ of moisture content, $20 \%$ of mechanical damages, $82 \%$ of seed germination, and $85 \%$ of seedling emergence. The main fungi associated to seeds were Aspergillus spp. (88.5\%) and Penicillium spp. (39.0\%).

After fungicide mixture application, reduction on population of microorganisms associated to seeds was observed as much for Aspergillus spp. as for Penicillium spp. (Table 1). According to recommendations, the fungicides mixture carboxin+ thiram $\left(50 \mathrm{~g}+50 \mathrm{~g}\right.$ a.i. $100 \mathrm{~kg}^{-1}$ seeds $)$ is used for controlling several microorganisms including Aspergillus spp. and Penicillium spp. Such result was essential for this study continuity, once with this procedure two incidence levels (high and low) were obtained for these storage fungi.

Table 1. Results of seed health test performed with seeds of the soybean, cv. M-SOY 7908 RR, treated with fungicide (low incidence of storage fungi) and non-treated with fungicide (high incidence of storage fungi).

\begin{tabular}{ccc}
\hline \multirow{2}{*}{ Incidence } & Aspergillus spp. & Penicillium spp. \\
\cline { 2 - 3 } & $\ldots \ldots \ldots \ldots \ldots(\%) \ldots \ldots \ldots \ldots \ldots . \ldots . \ldots \ldots$ \\
\hline High & $39.0 \mathrm{~b}^{*}$ & $88.5 \mathrm{~b}^{*}$ \\
Low & $2.0 \mathrm{a}$ & $17.5 \mathrm{a}$ \\
\hline CV $(\%)$ & 17.8 & 7.1 \\
\hline
\end{tabular}

*Means followed by the same letter in columns are not statistically different by Tukey test, at $1 \%$ probability.

The moisture content determination at the end of hydropriming indicated that seeds had between $32,1 \%$ and $36,2 \%$ moisture. The homogeneity of moisture content among seeds suggests that there is similarity of metabolic activity what allows identifying only the differences among treatments used within this study. Values for seed moisture content achieved may be considered satisfactory in function of results of other studies with soybean seeds, such as those obtained by Giurizatto et al. (2008), in which seed moisture content was approximately $30 \%$.

The summary of ANOVA (Table 2) indicated interaction between incidence of storage fungi and hydropriming of seeds for results on germination, first count, and accelerated aging test. Therefore, only results of these interactions were shown on Table 3. However, once there was no interaction for results of seedling emergence $\times$ seedling emergence speed index, only results related to storage fungi and hydropriming were shown.

Germination test results (Table 3) from seeds nonhydroprimed (without) indicated alteration of the number of normal seedlings by microorganisms, whose values for seed with low incidence surpassed the values for seeds with high incidence of Aspergillus spp. and Penicillium spp. The same results were observed to hydropriming seeds (Table 3). 
These results are compatible with information provided by Bittencourt et al. (2007), who have affirmed that reduction on population of microorganisms by seed treatment has potential in promoting benefits to seed germination, thus favoring increase on number of normal seedling. Still in relation to seed germination, it was verified that for seeds with high fungi incidence the hydropriming was prejudicial due to increased development of these microorganisms on the seeds (Table 3).

Table 2. F values obtained by ANOVA for tests of: germination (G); first count of germination (FC); accelerated aging (AA); seedling emergence (SE), and seedling emergence speed index (SESI), performed on seeds of soybean, cv. M-SOY 7908 RR and assessed after hydropriming.

\begin{tabular}{|c|c|c|c|c|c|}
\hline Sources of variation & G & $\mathrm{FC}$ & AA & SE & SESI \\
\hline Incidence of fungi (I) & $107.79^{* *}$ & $355.20^{* *}$ & $236.27^{* *}$ & $9.90^{* *}$ & $10.84^{* *}$ \\
\hline Hydropriming $(\mathrm{H})$ & $23.47^{* *}$ & $7.38^{* *}$ & $0.27^{* *}$ & $0.02^{\text {n.s. }}$ & $0.31^{\text {n.s. }}$ \\
\hline Interaction $\mathrm{I} \times \mathrm{H}$ & $17.25^{* *}$ & $66.46^{* *}$ & $48.94^{* *}$ & $1.56^{\mathrm{n} . \mathrm{s}}$ & $1.12^{\mathrm{n} . \mathrm{s}}$ \\
\hline CV (\%) & 7.4 & 5.6 & 17.0 & 8.5 & 9.7 \\
\hline
\end{tabular}

** = Significant at $5 \%$ and $1 \%$, respectively; ${ }^{\text {n.s. }}=$ non-significant.

Such fact may be explained by combination of temperature of $20^{\circ} \mathrm{C}$, continuous increase of seed moisture content, and drying at $30{ }^{\circ} \mathrm{C}$ during hydropriming what favored fungal development, thus justifying germination reduction. Nascimento and West (1998) had already stated that for enduring the process of priming, only seeds free of microorganisms should be used, once conditions needed for such procedure also contribute for fungi proliferation.

In this study, when hydropriming was applied to seeds with low incidence of microorganisms, similarities were observed for number of normal seedling originating from seeds with or without hydropriming, evidencing that when seeds have low indexes of fungi infestation the hydropriming procedure does not interfere on number of normal seedlings. Similar results have already been reported by Braccini et al. (1997), who have not observed differences on germination between non-primed and primed seeds into an osmotic solution containing the fungicide thiram.

Results of first count of germination (Table 3) have shown statistically significant differences for interaction between hydropriming and incidence of storage fungi. For seeds without hydropriming, the low incidence of these fungi allowed development of a higher number of normal seedlings in the first count than seeds with high incidence of these microorganisms. For the seeds with hydropriming results were similar to those found in the first count of the germination test, although with larger number of normal seedlings for seeds with low incidence of microorganisms. Thus, it is possible to affirm that reduction on incidence of storage fungi has allowed a faster seed germination resulting on seedlings more developed already in the first count of the germination test (larger than $6.5 \mathrm{~cm}$ ), independently if seeds have been submitted to hydropriming or not.
Table 3. Results of tests of germination, first count, and accelerated aging performed on soybean seeds, cv. M-SOY 7908 RR, with or without hydropriming and with high or low incidence of storage fungi.

\begin{tabular}{cccc}
\hline \multirow{2}{*}{ Assessments } & \multirow{2}{*}{ Fungi incidence } & \multicolumn{2}{c}{ Hydropriming } \\
\cline { 3 - 4 } & & with & without \\
\hline \multirow{2}{*}{ Germination (\%) } & High & $62 \mathrm{bB}^{*}$ & $81 \mathrm{bA}^{*}$ \\
& Low & $93 \mathrm{aA}$ & $94 \mathrm{aA}$ \\
\hline \multirow{2}{*}{ First count (\%) } & High & $51 \mathrm{bB}$ & $66 \mathrm{bA}$ \\
& Low & $90 \mathrm{aA}$ & $82 \mathrm{aB}$ \\
\hline \multirow{2}{*}{ Accelerated aging (\%) } & High & $14 \mathrm{bB}$ & $32 \mathrm{bA}$ \\
& Low & $73 \mathrm{aA}$ & $54 \mathrm{aB}$ \\
\hline
\end{tabular}

*Means followed by the same upper case letter in lines and lower case letter in columns are not statistically different by Tukey test, at $5 \%$ probability.

In relation to high incidence of storage fungi, still to first count, it was observed that seeds submitted to hydropriming were impaired mainly because of higher amounts of Aspergillus spp. and Penicillium spp, in relation to seeds without hydropriming "High". However, for seeds with low incidence of these microorganisms, the hydropriming obtained the number of seedlings, to first count, higher than the number of seedlings originating from seeds without hydropriming, so, ratifying the benefits of this technique. Thus, it was possible verifying that when a high incidence of microorganisms occurred on seeds, the hydropriming procedure has not favored the occurrence of normal seedlings in the first count of germination test; however, when seeds with low incidence of microorganisms have submitted to hydropriming such benefits were highlighted, in function of the higher number of normal seedlings.

Nunes et al. (2004) also have verified that priming by hydropriming has promoted benefits to soybean seeds originating from different seed lots, with statistically significant 
increments on number of normal seedlings in the first count of the germination test in relation to control. Lima and Marcos-Filho (2010), working with cucumber seeds, observed increase on number of normal seedlings in the first count of the germination test; Peske and Novembre (2010) have also obtained similar results for seeds of millet. However, Braccini et al. (1997) did not observe differences on results achieved on first count of germination test between seeds submitted to osmopriming with fungicide and control.

According to Mendonça et al. (2005) and Nascimento et al. (2009), the priming results in increase of seed germination speed; once some metabolic and cellular changes occur, this way favoring fast germination of the seeds. This information ratifies the results attained, which have indicated a higher number of normal seedlings in the first count. By results obtained in the accelerated aging test (Table 3), in reference to interaction between storage fungi $\times$ hydropriming, it was found that when compared the results obtained for seeds without hydropriming, the low incidence of microorganisms contributed for increases of number of normal seedlings, with results higher than for seeds with high incidence. It was observed that also for seeds with hydropriming similar results was found with superiority for seeds with low incidence of microorganisms. Therefore, these results indicate that reduction on amount of microorganisms on seeds is essential for maintenance of their quality; independently if the seeds were submitted to hydropriming or not.

However, for seeds with high incidence of microorganisms it was observed that the hydropriming technique was prejudicial to seeds, once number of normal seedlings obtained after the accelerated aging test was lower than those obtained for control seeds (without hydropriming). The large initial amount of inoculum on the seeds contributed for reduction of their quality (Table 3). However, when performed on seeds with low incidence of storage fungi, the hydropriming procedure results, achieved in the accelerated aging test, were higher than to results found for seeds without hydropriming.

Although seeds had not been assessed for biochemical conditions, the results of seeds with low incidence of microorganisms submitted to hydropriming indicate that there was activation of some repair mechanisms that were not sufficient to change results of germination test (Table 3), however influenced the seed vigor, as observed for the accelerated aging test results. Based on such fact, several results of studies attest to the benefits resulting from priming, such as repair of deterioration damages (Ruan et al., 2002) and increase on synthesis and activity of enzymes (Basra et al., 2005), what may justify results attained.

Thus, reduction on incidence of microorganisms on soybean seeds by chemical treatment was efficient for evidence the priming effects. Dias et al. (2009) have affirmed that seed treatment with fungicide are recommendable for seeds submitted to priming, once such practice favor maintenance of the seed quality.

There was no interaction between seedling emergence and seedling emergence speed index, and, so, both treatments were independent for these two parameters (Table 2). Results achieved for the seeds with low incidence of microorganisms were statistically higher than to results achieved for seed with high incidence of these microorganisms, as much for seedling emergence as for seedling emergence speed index (Table 4).

Table 4. Results of tests of seedling emergence (SE) and seedling emergence speed index (SESI) performed on soybean seeds, cv. M-SOY 7908 RR, with or without hydropriming and high or low incidence of storage fungi.

\begin{tabular}{|c|c|c|}
\hline Sources of variation & $\mathrm{SE}(\%)$ & SESI \\
\hline \multicolumn{3}{|c|}{$\begin{array}{l}\text { Fungi incidence } \\
\end{array}$} \\
\hline High & $80 b^{*}$ & $7.9 b^{*}$ \\
\hline Low & $88 \mathrm{a}$ & $8.9 \mathrm{a}$ \\
\hline \multicolumn{3}{|c|}{ Hydropriming } \\
\hline With & $84 \mathrm{a}$ & $8.5 \mathrm{a}$ \\
\hline Without & $84 \mathrm{a}$ & $8.3 \mathrm{a}$ \\
\hline
\end{tabular}

*Means followed by the same upper case letter in lines are not statistically different by Tukey test, at $5 \%$ probability.

Besides there was not statistically significant difference between results achieved for seeds with or without hydropriming. Thus, during this study the adverse environmental conditions prevailing in the greenhouse and common during emergence of seedlings were not sufficient to interfere either in the emerged seedling number or on speed of such process. However, there is environmental variation when the sowing is performed under field conditions and consequently it is possible observing beneficial effects of hydropriming, once results of some of the performed tests, such as the accelerated aging test and first count of germination, were statistically higher than the results achieved for seeds physiologically conditioned by hydropriming and with low incidence of fungi.

\section{Conclusions}

The hydropriming is beneficial to improve the quality of soybean seeds with low incidence of storage fungi with increments on speed of germination (first count) and seed germination after accelerated aging test. The high incidence of microorganisms can reduce the hydropriming benefits. 


\section{References}

ARIF, M.; JAN, M.T.; MARWAT, K.B.; KHAN, M.A. Seed priming improves emergence and yield of soybean. Pakistan Journal of Botany, v.40, n.3, p.11691177, 2008. http://www.pakbs.org/pjbot/PDFs/40(3)/PJB40(3)1169.pdf

BAALBAKI, R.; ELIAS, S.; MARCOS-FILHO, J.; McDONALD, M.B. (Eds.) Seed vigor testing handbook. Association of Official Seed Analysts. Contribution n.32 to the Handbook on Seed Testing. 2009. 346p.

BASRA, S.M.A.; FAROOQ, M.; TABASSAM, R.; AHMAD, N. Physiological and biochemical aspects of pre-sowing seed treatments in fine rice (Oryza sativa L.). Seed Science and Technology, v.33, n.3, p.623-628, 2005.

BEJANDI, T.K.; SEDGHI, M.; SHARIFI, R.S.; NAMVAR, A.; MOLAEI, P. Seed priming and sulfur effects on soybean cell membrane stability and yield in saline soil. Pesquisa Agropecuária Brasileira, v.44, n.9, p.1114-1117, 2009. http://www.scielo.br/pdf/pab/v44n9/v44n9a07.pdf

BITTENCOURT, S.R.M.; MENTEN, J.O.M; ARAKI, C.A.S.; MORAES, M.H.D.; RUGAI, A.R.; DIEGUEZ, M.J.; VIEIRA, R.D. Eficiência do fungicida carboxin + thiram no tratamento de sementes de amendoim. Revista Brasileira de Sementes, v.29, n.2, p.214-222, 2007. http://www.scielo.br/pdf/ rbs/v29n2/v29n2a28.pdf

BRACCINI, A.L.; REIS, M.S.; SEDIYAMA, C.S.; ROCHA, V.S.; SEDIYAMA, T. Efeito do condicionamento osmótico na germinação e no vigor de sementes de soja. Revista Brasileira de Sementes, v.19, n.1, p.7179, 1997. http://www.abrates.org.br/revista/artigos/1997/v19n1/artigo14.pdf

BRADFORD, K.J. Manipulation of seed water relations via osmotic priming to improve germination under stress conditions. Hort Science, v.21, n.5, p.1105-1112, 1986.

BRASIL. Instrução normativa n ${ }^{\circ} 25$, de 16 de dezembro de 2005: Padrão para produção e comercialização de sementes de soja. Diário Oficial da União, Brasília, 2005. n.243, Seção 1, p.2.

BRASIL. Ministério da Agricultura, Pecuária e Abastecimento. Regras para análise de sementes. Ministério da Agricultura, Pecuária e Abastecimento. Secretaria de Defesa Agropecuária. Brasília, DF: MAPA/ACS, 2009. 395p. http://www.agricultura.gov.br/arq_editor/file/laborat $\%$ c3\%b3rio/sementes/ regras $\% 20$ para $\% 20$ analise $\% 20 \mathrm{de} \% 20$ sementes.pdf

CASEIRO, R.F.; MARCOS-FILHO, J. Métodos para a secagem de sementes de cebola submetidas ao condicionamento fisiológico. Horticultura Brasileira, v.23, n.4, p.887-892, 2005. http://www.scielo.br/pdf/hb/v23n4/ a05v23n4.pdf

CARDOSO, P.C.; BAUDET, L.; PESKE, S.T.; LUCCA FILHO, O.A. Armazenamento em sistema a frio de sementes de soja tratadas com fungicida. Revista Brasileira de Sementes, v.26, n.1, p.15-23, 2004. http:// www.scielo.br/pdf/rbs/v26n1/a03v26n1.pdf

COSTA, C.J.; VILLELA, F.A. Condicionamento osmótico de sementes de beterraba. Revista Brasileira de Sementes, v.28, n.1, p.21-29, 2006. http:// www.scielo.br/pdf/rbs/v28n1/a04v28n1.pdf

DIAS, M.A.; AQUINO, L.A.; DIAS, D.C.F.S.; ALVARENGA, E.M. Qualidade fisiológica de sementes de beterraba (Beta vulgaris L.) sob condicionamento osmótico e tratamentos fungicidas. Revista Brasileira de Sementes, v.31, n.2, p.188-194, 2009. http://www.scielo.br/pdf/rbs/v31n2/v31n2a22.pdf

FANAN, S.; NOVEMBRE, A.D.L.C. Condicionamento fisiológico de sementes de berinjela. Bragantia, v.66, n.4, p.675-683, 2007. http://www. scielo.br/pdf/brag/v66n4/18.pdf
FANTI, S.C.; PEREZ, S.C.J.G.A. Efeito do estresse hídrico e envelhecimento precoce na viabilidade de sementes osmocondicionadas de paineira (Chorisia speciosa). Pesquisa Agropecuária Brasileira, v.38, n.4, p.537-543, 2003. http://www.scielo.br/pdf/pab/v38n4/a13v38n4.pdf

FRANCISCO, F.G.; USBERTI, R. Seed health of common bean stored at constant moisture and temperature. Scientia Agricola, v.65, n.6, p.613-619, 2008. http://www.scielo.br/pdf/sa/v65n6/07.pdf

GIURIZATTO, M.I.K.; ROBAINA, A.D.; GONÇALVES, M.C.; MARCHETTI, M.E. Qualidade fisiológica de sementes de soja submetidas ao hidrocondicionamento. Acta Scientiarum Agronomy, v.30, n.5, p.711-717, 2008. http://eduem.uem.br/ojs/index.php/ActaSciAgron/ article/view/5972/5972

KIKUTI, A.L.P.; MARCOS-FILHO, J. Condicionamento fisiológico de sementes de couve-flor. Horticultura Brasileira, v. 27, n.2, p.240-245, 2009. http://www.scielo.br/pdf/hb/v27n2/v27n2a21.pdf

KIKUTI, A.L.P.; KIKUTI, H.; MINAMI, K. Condicionamento fisiológico em sementes de pimentão. Revista Ciência Agronômica, v.36, n.2, p.243-248, 2005. http://www.ccarevista.ufc.br/seer/index.php/ccarevista/article/view/270/265

KRZYZANOWSKI, F.C.; FRANÇA-NETO, J.B.; COSTA, N.P. Teste do hipoclorito de sódio para semente de soja. Londrina: EMBRAPA, CNPSo, 2004. 4p. (Circular Técnica, 37).

LIMA, L.B.; MARCOS-FILHO, J. Condicionamento fisiológico de sementes de pepino e germinação sob diferentes temperaturas. Revista Brasileira de Sementes, v.32, n.1, p.138-147, 2010. http://www.scielo.br/pdf/rbs/v32n1/v32n1a16.pdf

LIMA, S.M.P.; GUIMARÃES, R.M.; OLIVEIRA, J.A.; VIEIRA, M.G.G.C. Efeitos de tempos e temperaturas de condicionamento sobre a qualidade fisiológica de sementes de cafeeiro (Coffea arabica, L.) sob condições ideais e de estresse térmico. Ciência e Agrotecnologia, v.28, n.3, p.505-514, 2004. http://www.scielo.br/pdf/cagro/v28n3/04.pdf

MAGUIRE, J.D. Speed of germination aid in selection and evaluation for seedling emergence and vigor. Crop Science, v.2, n.2, p.176-177, 1962.

MENDONÇA, A.V.R.; COELHO, E.A.; SOUZA, N.A.; BALBINOT, E.; SILVA, R.F.; BARROSO, D.G. Efeito da hidratação e do condicionamento osmótico em sementes de pau-formiga. Revista Brasileira de Sementes, v.27, n.2, p.111-116, 2005. http://www.scielo.br/pdf/rbs/v27n2/a16v27n2.pdf

MERCADO, M.F.O.; FERNANDEZ, P.G. Solid matrix priming of soybean seeds. Philippine Journal of Crop Science, v.27, n.2, p.27-35, 2002. http:// www.cabi.org/gara/fulltextpdf/2009/20093019273.pdf

NASCIMENTO, W.M. Preventing thermoinhibition in a thermosensitive lettuce genotype by seed imbibition at low temperature. Scientia Agricola, v.60, n.3, p.477-480, 2003. http://www.scielo.br/pdf/sa/v60n3/16401.pdf?q=embebidas

NASCIMENTO, W.M.; ARAGÃO, F.A.S. Condicionamento osmótico de sementes de melão: absorção de água e germinação em diferentes temperaturas. Revista Brasileira de Sementes, v.24, n.1, p.153-157, 2002. http://www.scielo.br/pdf/rbs/v24n1/v24n1a22.pdf

NASCIMENTO, W.M.; SILVA, J.B.C.; SANTOS, P.E.C.; CARMONA, R. Germinação de sementes de cenoura osmoticamente condicionadas e peletizadas com diversos ingredientes. Horticultura Brasileira, v.27, n.1, p.12-16, 2009. http://www.scielo.br/pdf/hb/v27n1/03.pdf

NASCIMENTO, W.M.; WEST, S.H. Microorganism growth during muskmelon seed priming. Seed Science and Technology, v.26, n.2, p.531-534, 1998.

NUNES, U.R.; REIS, M.S.; DEL GIÚDICE, M.P.; SEDIYAMA, C.S.; 
SEDIYAMA, T. Qualidade fisiológica e sanitária de sementes de soja submetidas ao condicionamento fisiológico. Revista Ceres, v.51, n.294, p.163-177, 2004. http://www.scielo.br/pdf/fb/v32n6/a02v32n6.pdf

PEREIRA, M.D.; DIAS, D.C.F.S.; DIAS, L.A.S.; ARAÚJO, E.F. Germinação e vigor de sementes de cenoura osmocondicionadas em papel umedecido e solução aerada. Revista Brasileira de Sementes, v.30, n.2, p.137-145, 2008. http://www.scielo.br/pdf/rbs/v30n2/a17v30n2.pdf

PESKE,F.B.; NOVEMBRE,A.D.L.C.Condicionamentofisiológicodesementes de milheto. Revista Brasileira de Sementes, v.32, n.4, p.132-142, 2010. http:// www.scielo.br/scielo.php?pid=s0101-31222010000400015\&script=sci_arttext
RUAN, S.; XUE, Q.; TYLKOWSKA, K. The influence of priming on germination of rice Oryza sativa L. seeds and seedling emergence and performance in flooded soil. Seed Science and Technology, v.30, n.1, p.61-67, 2002.

SADEGHI, H.; KHAZAEI, F.; YARI, L.; SHEIDAEI, S. Effect of seed osmopriming on seed germination behavior and vigor of soybean (Glycine max L.). Journal of Agricultural and Biological Science, v.6, n.1, p.39-43, 2011. http://www.arpnjournals.com/jabs/researchpapers/rp_2011/jabs_0111_231.pdf 